\title{
PERANCANGAN KONFIGURASI SISTEM ROBOT LINE FOLLOWER PEMANTAU KONDISI JALAN
}

\author{
Ferdi Sanofel ${ }^{1}$ \\ ${ }^{1}$ Prodi Teknik Elektro UNPAM \\ Jln. Puspiptek Raya No 46 Buaran, Setu - Tangerang Selatan 15310 \\ dosen01323@unpam.ac.id
}

\begin{abstract}
ABSTRAK
Keinginan manusia untuk meringankan pekerjaan sehari-hari, ada inisiatif untuk menciptakan alat bantu berupa robot. Berbagai robot mulai diciptakan dan digunakan untuk membantu pekerjaan manusia salah satunya adalah mobile robotic dan humanoid robotic. Sistem kerja dari robot ini hamper sama dengan manusia yaitu bergerak, melangkah, memegang dan berbicara. Alat bantu yang digunakan adalah Arduino uno ATmega 328 yang mendukung untuk interface antara hardware dengan software dihunungkan dengan catu daya. Sensor LDR sebagai alat yang dapat mendeteksi intensitas cahaya dalam keadaan gelap dan terang. Menggunakan limit switch sebagai pengatur NO (Normali Open) dan NC (Normali Close) pada rangkaian. Motor servo dilengkapi dengan sensor accelerometer guna pengukuran percepatan, deteksi dan pengukur getaran. Tujuan penelitian ini adalah untuk mendeteksi posisi kemiringan dari robot line follower, untuk memastikan jalan yang di lewati oleh robot tersebut aman. Karena jika kondisi jalan terlalu miring, robot bisa jatuh, data dari kondisi jalan juga bisa didapatkan dan dikirim melalui media bluetooth. Simpangan kesalahan dari pengukuran berkisar $20 \%$, hal ini dikarenakan kesulitan pada saat mengkalibrasi alat sehingga besaran kemiringan sudut yang didapat belum menggambarkan kondisi yang sebenarnya. Kelebihan dari alat ini adalah pengaksesan data hasil pengukuran bisa diketahui melalui perangkat lain seperti computer, android dan tablet yang mempunyai aplikasi komunikasi dengan perangkat arduino.
\end{abstract}

Kata kunci: Arduino atmega328, mobile robotic, motor servo, sensor accelerometer, sensor LDR.

\begin{abstract}
CONFIGURATION DESIGN OF ROBOT LINE FOLLOWER MONITOR CONDITION OF ROAD CONDITION. Human desire to lighten daily work, there are initiatives to create tools such as robots. Various robots began to be created and used to help human work, one of which is mobile robotic and humanoid robotic. The working system of this robot is almost the same as humans, namely moving, stepping, holding and talking. The tool used is Arduino uno ATmega 328 which supports interfaces between hardware and software connected to the power supply. LDR sensor as a tool that can detect the intensity of light in dark and bright conditions. Using the limit switch as a regulator NO (Normali Open) and NC (Normali Close) on the circuit. Servo motor is equipped with an accelerometer sensor for measuring acceleration, detection and measuring vibration. The purpose of this study is to detect the tilt position of the line follower robot, to ensure the path traveled by the robot is safe. Because if the road conditions are too tilted, the robot can fall, data from the road conditions can also be obtained and sent via Bluetooth media. The error deviation of the measurement is around $20 \%$, this is due to the difficulty when calibrating the device so that the magnitude of the slope obtained does not reflect the actual conditions. The advantage of this tool is accessing measurement results data can be known through other devices such as computers, Android and tablets that have communication applications with Arduino devices.
\end{abstract}

Keywords: Arduino atmega328, mobile robotic, servo motor, accelerometer sensor, LDR sensor. 


\section{PENDAHULUAN}

$\mathrm{K}$ einginan manusia untuk membuat peralatan yang dapat membantu meringankan pekerjaan manusia dalam memenuhi kebutuhan hidup, membuat manuasia berpikir mengembangkan berbagai macam peralatan. Dari peralatan yang sederhana sampai peralatan yang cukup sulit dan rumit, baik dalam proses pembuatan maupun dalam proses pengoperasian. Dahulu manusia mungkin hanya berpikir membuat peralatan hanya untuk meringankan pekerjaan sehari-hari. Tapi untuk saat ini peralatan yang dikembangkan tidak hanya untuk membantu pekerjaan manusia sehari-hari tapi juga dikembangkan peralatan yang dapat membantu dalam proses produksi barang dan alasan - alasan lainnya.

Beberapa teknologi robot yang sedang dikembangkan saat ini diantaranya: Mobile Robotic dan Humanoid Robotic. Mobile robotic adalah robot yang pergerakan dan perpindahannya menggunakan roda. Sedangkan Humanoid Robotic adalah robot yang cara pergerakan dan perpindahannya menyerupai pergerakan manusia seperti melangkah, memegang dan berbicara.

Mobile robot merupakan robot yang terbilang sederhana jika dibandingkan dengan humanoid robot, dikarenakan jumlah peralatan system dan $1 / O$ yang digunakan tidak terlalu banyak dan kompleks. Contohnya pada mobile robot untuk bergerak maju atau mundur kita tinggal mengatur putaran roda sejauh yang kita inginkan, sedangkan pada humanoid robot untuk bergerak maju atau mundur banyak sekali sensor dan pengatur gerakan mekanis yang harus digunakan untuk mendapatkan gerakan yang halus dan sempurna.

\section{TEORI}

\section{Arduino}

Berbentuk board yang berbasis mikrokontroler ATmega328. Jumlah input/output ada 14 pin, 6 pin output PWM, 6 pin input analog, $16 \mathrm{MHz}$ osilator Kristal, koneksi USB. Dalam Pin berisi semua yang diperlukan untuk mendukung mikrokontroler, penghubung ke computer menggunakan USB. Sedangkan utuk catu daya bisa menggunakan baterai atau adaptor AC-DC. Fitur Board arduino yaitu :

1. 1,0 pin out: SDA dan SCL

2. Circuit yang lebih kuat.

3. Atmega $16 \mathrm{U} 2$ yaitu $8 \mathrm{U} 2$

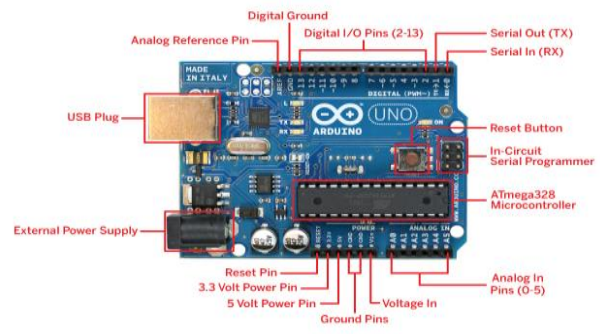

Gambar 1. Skema board arduino

Tabel 1. Deskripsi dari arduino Uno

\begin{tabular}{|l|l|}
\hline Mikrokontroler & ATmega328 \\
\hline Tegangan pengoperasian & $5 \mathrm{~V}$ \\
\hline $\begin{array}{l}\text { Tegangan input yang } \\
\text { disarankan }\end{array}$ & $7-12 \mathrm{~V}$ \\
\hline Batas tegangan input & $6-20 \mathrm{~V}$ \\
\hline Jumlah pin I/O digital & 14 (6 di antaranya menyediakan keluaran PWM) \\
\hline Jumlah pin input analog & 6 \\
\hline Arus DC tiap pin $\mathrm{IO}$ & $40 \mathrm{~mA}$ \\
\hline Arus DC untuk pin 3.3V & $50 \mathrm{~mA}$ \\
\hline Memori Flash & $32 \mathrm{~KB}$ (ATmega328), sekitar $0.5 \mathrm{~KB}$ digunakan oleh \\
\hline SRAM & bootloader \\
\hline EEPROM & $2 \mathrm{~KB}$ (ATmega328) \\
\hline Clock Speed & $1 \mathrm{~KB}$ (ATmega328) \\
\hline & $16 \mathrm{~Hz}$ \\
\hline
\end{tabular}

\section{Catu daya}

Arduino dapat di aktifkan dengan koneksi USB dan menggunakan catu daya eksternal. Supply listrik dipilih secara otomatis. Untuk power supply dari luar dapat berupa adaptor berupa AC atau DC atau dapat menggunakan baterai. Adaptor ini dihubungkan dengan memasang center positive plug panjang $2,1 \mathrm{~mm}$ ke jack catu daya board arduino. Lead baterai dimasukan kedalam header pin Gnd dan Vin dengan power.

Dapat bekerja pada tegangan antara 6$20 \mathrm{~V}$, akan tetapi apabila suplai tegangan yang masuk kurang dari 7V. Pin 5V Arduino mempunyai output $5 \mathrm{~V}$ yang menyebabkan arduino tidak stabil. Begitu juga sebaliknya apabila tegangan yang diberikan lebih dari 
$12 \mathrm{~V}$ yang terjadi adalah voltage regulator akan lebih cepat panas, dan kondisi ini juga tidak bagus untuk jangka panjang dan juga membahayakan arduino itu sendiri. Jadi tegangan yang dianjurkan adalah antara 7 $12 \mathrm{~V}$.

\section{Memori}

ATmega 328 terdiri dari $32 \mathrm{~KB}$ memori dan 0,5 sebagai bootloader. Dan terdiri $2 \mathrm{~KB}$ SRAM serta 1KB EEPROM

\section{Input Output}

14 pin digital arduino sebagai input/ output, fungsi pin mode (), digital write () dan digital read(). Batasan beroperasi adalah 5V. Setiap pin memberikan dan menerima batas maksimum $40 \mathrm{~mA}$ dan mempunyai resistor pull-up internal terdiri dari $20-50 \mathrm{~K} \Omega$.

\section{Komunikasi}

Arduino memiliki sejumlah fasilitas komunikasi terhubung dengan komputer. Atmega 328 menyediakan serial komunikasi UART TTL $(5 \mathrm{~V})$, yang tersedia pada pin digital $0(\mathrm{RX})$ dan 1 (TX).

\section{Pemograman}

Arduino diprogram menggunakan perangkat lunak.. ATmega328 hadir dengan sebuah bootloader pemogram mengirim kode baru ke ATmega 328 tanpa menggunakan pemogram hardware eksternal. ATmega 328 berkomunikasi menggunakan STK 500 asli. Bisa memberi jalan pintas ke bootloader dan program mikrokontroler melalui header ICSP (InCircuit Serial Programing)

\section{Sensor LDR (Light Depending Resistor)}

Pada saat sekarang ini hampir semua besaran fisik sudah bisa di terjemahkan kedalam kode-kode digital dengan berbagai macam manipulasi. Salah satu besaran fisik yang bisa dirubah kedalam kode digital adalah besaran intensitas cahaya.

Cara kerja dari sensor LDR adalah merubah nilai tahanan berdasarkan perubahan intensitas cahaya yang diterima. Nilai resistansi LDR pada saat gelap adalah sebesar $10 \mathrm{M} \Omega$, sedangkan pada saat terang sebesar $1 \mathrm{~K} \Omega$.

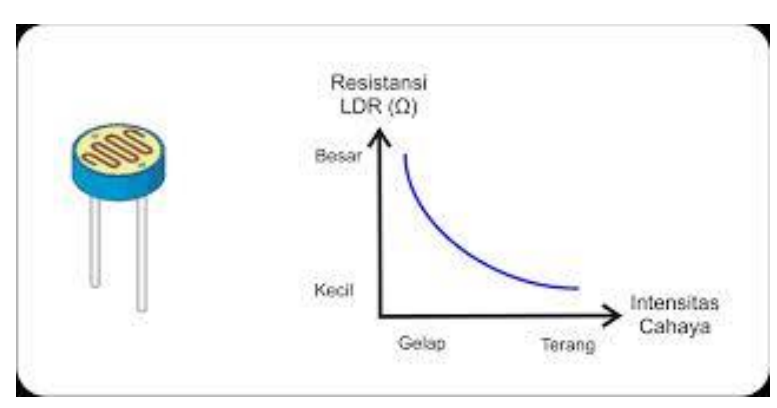

Gambar 2. Gambar karakteristik LDR

\section{Limit Switch}

Digunakan untuk mendeteksi benda benda yang ada bersentuhan langsung dengan peralatan yang menggunakannya. Limit switch mempunyai cara kerja yang sangat sederhana, pada saat tuas dari limit switch mengenai suatu benda dan tertekan maka kontak NO/NC yang ada di limit switch akan berubah. Nilai dari perubahan inilah yang kita gunakan dan diolah lebih lanjut sesuai dengan keperluan.

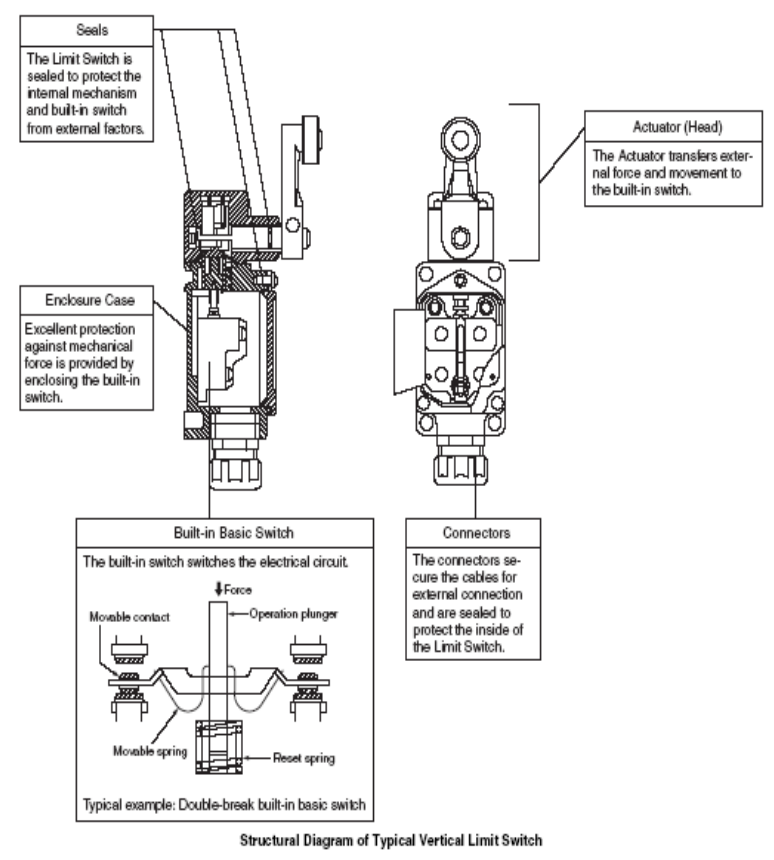

Gambar 3. Gambaran cara kerja limit switch

\section{Motor Servo}

Menggunakan sistem closed feedback dengan posisi dari motor yang diinformasikan kembali ke dalam rangkaian kontrol yang ada di motor servo. Motor ini terdiri dari motor DC, gear, potensio meter serta rangkaian kontrol. 


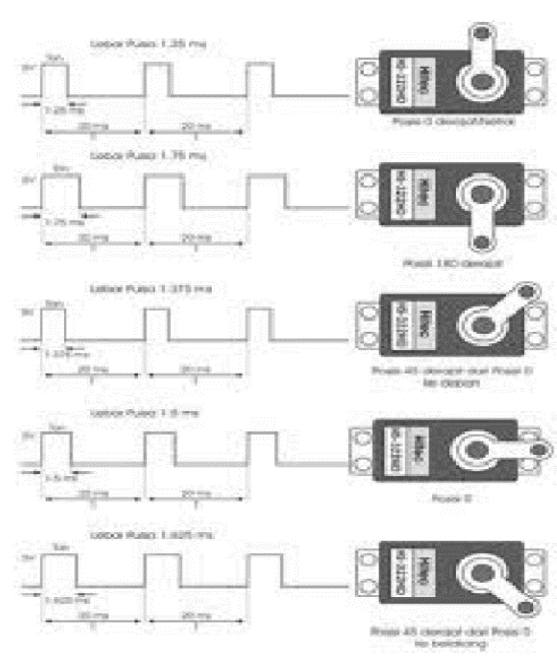

Gambar 4. Pengendalian motor servo standar

\section{Sensor Accelerometer}

Sebuah sensor tranduser sebagai pengukur percepatan, pendeteksi dan dapat mengukur getaran. Prinsip kerja tranduser ini berdasarkan hukum fisika, apabila suatu konduktor digerakkan melalui suatu medan magnet, atau jika suatu medan magnet digerakkan melalui suatu konduktor, maka akan timbul suatu tegangan induksi pada konduktor tersebut.
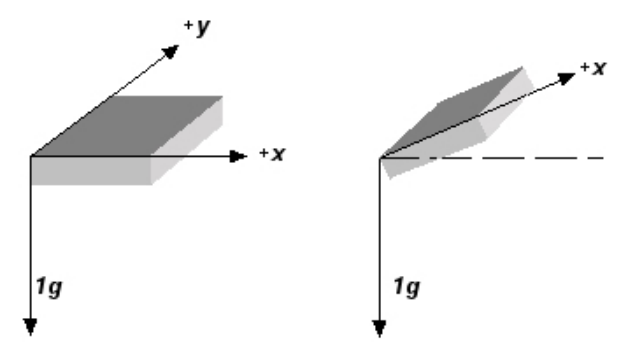

Gambar 5. Ilustrasi sudut pengukuran sudut sumbu (x) dan sumbu (y)

Cara mengukur kemiringan kedua sumbu $x$ dan y adalah accelerometer 2sumbu maka hanya dapat menggunakan sin-1(a) dimana a yaitu output accelerometer satu sumbu. Diluar sudut kemiringan 45 dan -45 derajat maka akurasinya semakin berkurang. Pengurangan resolusi serta akurasi melebihi 45 derajat kemiringan tersebut dapat kita lakukan dengan memakai 2 sumbu pengukur kemiringan. Komponen gravitasi bekerja pada sumbu $x$ yaitu fungsi sinus, pada sumbu y yaitu fungsi kosinus.

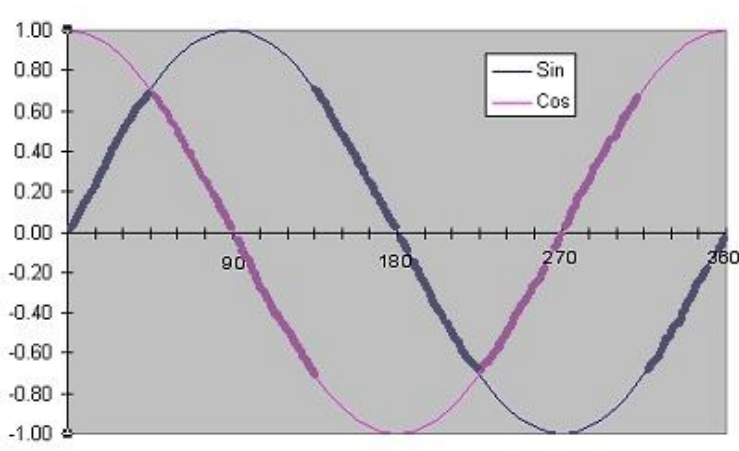

Gambar 6. Bagian sensitif dari sebuah gelombang sinus sudut pengukuran accelerometer

Jadi, dengan menggabungkan antara sumbu $x$ dan sumbu y maka akan diperoleh keakuratan yang lebih baik.

\section{METODOLOGI}

Ada beberarapa hal yang harus diperhatikan dalam perancangan dan rencana pengukuran. Diantaranya adalah bentuk alat yang akan dibuat, meliputi dimensi, dan tata letak sensor. Desain dari lintasan yang akan dilewati oleh robot sebagai ujicoba, dan rencana pengambilan data dari masing-masing sensor yang akan digunakan.

\section{Konfigurasi Alat}

Konfigurasi alat yang dimaksud adalah cara kerja dari alat yang dirancang, ukuran dan bentuk dari alat, tata letak komponen, dan jalur lintasan sebagai ujicoba alat.

\section{Desain Robot}

Bahan yang digunakan untuk merakit rangka dari robot line follower ini adalah dari bahan acrylic dengan ukuran $5 \mathrm{~mm}$. adapun untuk rangka terbagi atas beberapa bagian :

\section{Rangka Atas}

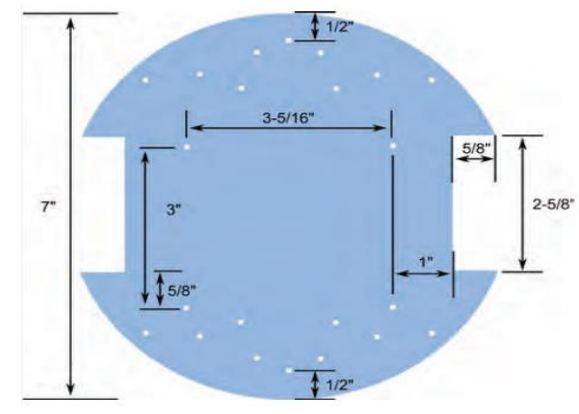


Gambar 7. Sketsa rangka bawah robot

Gambar diatas adalah ukuran dari rangka bawah robot yang berfungsi untuk penempatan rangkaian catu daya, rangkaian pengontrol sensor LDR, motor servo dan limit switch.

\section{Rangka Bawah}

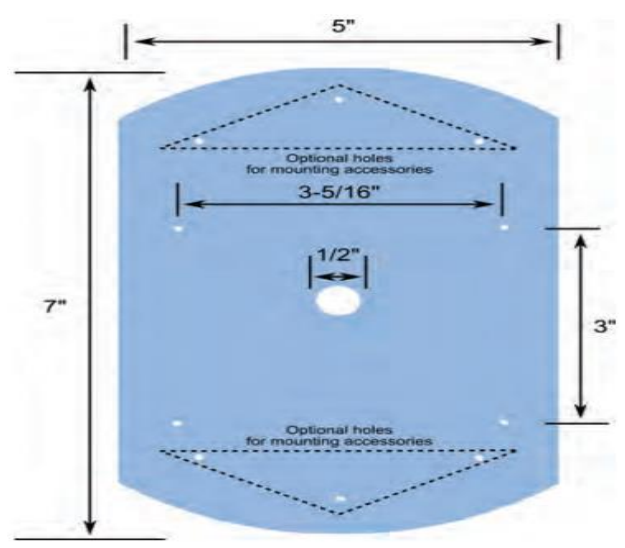

Gambar 8. Sketsa rangka atas robot

Gambar diatas adalah bagian rangka atas dari robot yang berguna untuk menempatkan arduino dan sensor accelerometer.

\section{Desain Lintasan yang akan dilewati}

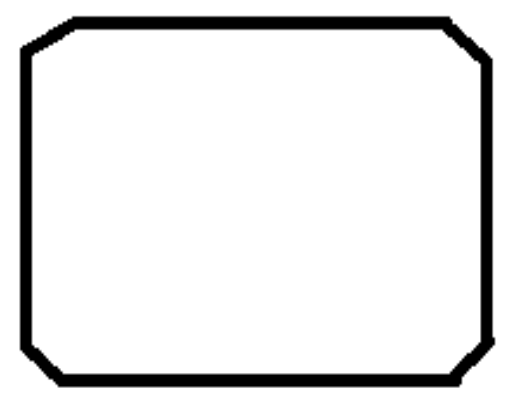

Gambar 9. Layout lintasan yang akan dilewati

Gambar diatas adalah bentuk lintasan yang akan dilintasai oleh robot, diharapkan nanti perangkat dapat berbelok mengikuti lintasan yang sudah ditetapkan. Diharapkan juga pada saat robot berbelok - belok mengikuti lintasan perangkat akan mengirimkan informasi melalui media Bluetooth, agar bisa diketahui titik - titik dimana perangkat berbelok, melalui lintasan yang menanjak, menurun ataupun melewati jalan jalan dengan kemiringan tertentu.

\section{Penggabungan Sistem}

Penggabungan dari masing-masing bagian robot yang sudah disiapkan adalah sebagai berikut:

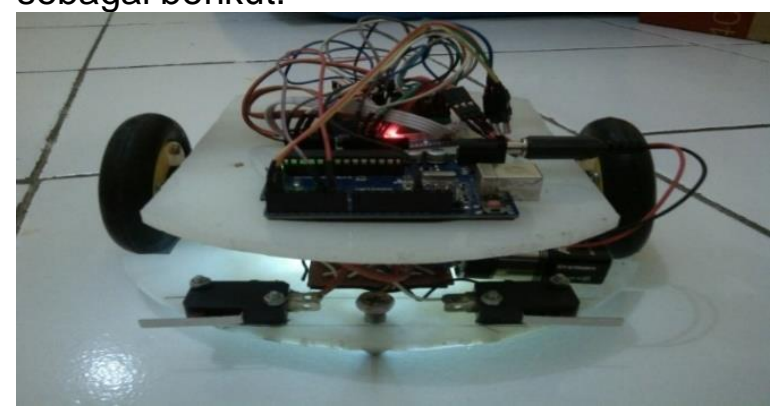

Gambar 10. Tampak depan

\section{HASIL DAN PEMBAHASAN}

\section{Alur Cara Kerja Robot}

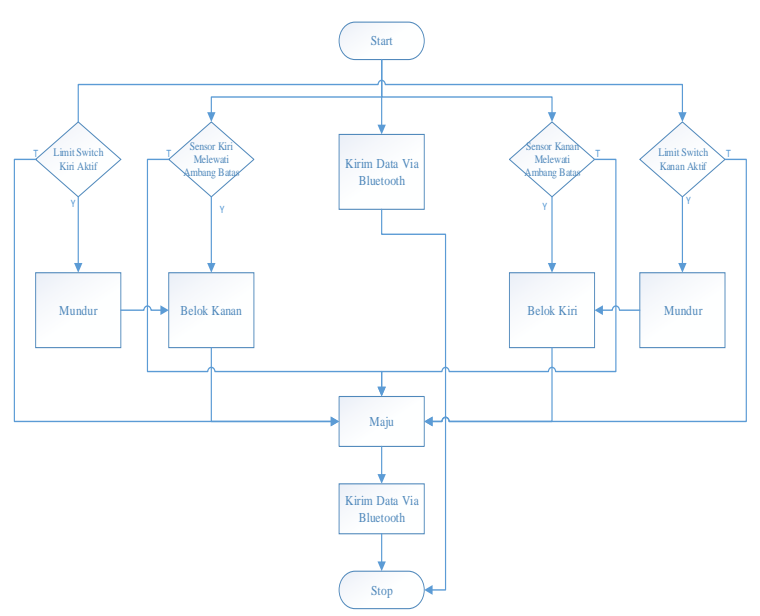

Gambar 11. Alur kerja robot

Alur kerja dari gambar diatas lebih kurang sebagai berikut:

Pada saat perangkat diaktifkan, sensor LDR akan langsung bekerja memonitor pergerakan perangkat agar tetap berada pada jalur yang sudah ditentukan.

Limit switch baru akan bekerja pada saat perangkat menabrak atau menyentuh penghalang didepannya. Apabila kedua limit switch tertekan maka akan di asumsikan bahwa robot harus mundur agak jauh kebelakang sambil mendeteksi jalur lintasan apakah sudah benar atau salah. Tetapi apabila salah satu dari limit switch yang tertekan maka bisa di asumsikan kalau 
perangkat harus menghindar kekiri atau ke kanan.

Pada saat perangkat robot melewati lintasan yang menanjak atau menurun, maka accelerometer akan langsung bekerja mendeteksi berapa derajat dari kemiringan dari lintasan tersebut. Kondisi lintasan yang bergelombang bisa di asumsikan oleh robot apabila fluktuasi sudut kemiringan lintasan yang diberikan oleh accelerometer terjadi sangat cepat.

\section{Tabel Pengukuran Sensor}

Tabel pengukuran didapatkan setelah melakukan pengujian - pengujian terhadap alat - alat atau komponen pendukung seperti sensor, limit switch, dan motor servo. Table ini berguna untuk membantu mengetahui cara kerja dari dari perangkat perangkat tersebut, sehingga diharapkan bisa mempermudah dan mempercepat dalam perakitan nantinya.

\section{Sensor LDR}

Cara pengambilan data ini adalah menempatankan sensor LDR pada tabel warna dengan jarak $2,5 \mathrm{~cm}$. Cahaya sekeliling tidak direduksi terlebih dahalu karena tidak dipasang led. Pengukuran dilakukan berkali - kali agar didapatkan data yang lebih meyakinkan, untuk menghindari kesalahan dari pengambilan kesimpulan.

Tabel 2. Pengukuran LDR

\begin{tabular}{|c|c|}
\hline $\begin{array}{c}\text { Kondisi warna } \\
\text { lintasan }\end{array}$ & $\begin{array}{c}\text { Nilai Resistasi (k } \\
\Omega \text { ) }\end{array}$ \\
\hline & 8,84 \\
\hline & 9,47 \\
\hline & 10,56 \\
\hline & 11,25 \\
\hline & 13,85 \\
\hline & 14,46 \\
\hline & 16,95 \\
\hline & 19,74 \\
\hline & 22,74 \\
\hline
\end{tabular}

Bila diperhatikan hasil pengukuran kepekaan LDR terhadap warna diatas, dapat diketahui bahwa nilai resistansi pada LDR akan berkurang atau bernilai kecil apabila mendeteksi warna putih atau warna yang lebih terang. Dan akan bernilai besar atau mempunyai hambatan yang tinggi apabila bertemu warna hitam atau warna yang lebih gelap. Berdasarkan hasil pengukuran diatas dapat diketahui juga apabila LDR dihubungkan dengan sebuah rangkaian dan diberi tegangan dan kemudian dilakukan pengukuran maka nilai tegangan yang didapatkan juga akan berubah - ubah seiring dengan berubahnya nilai resistansi dari LDR. Perubahan tegangan ini bisa langsung dideteksi oleh input analog pada arduino, sehingga bisa didapat kan satu nilai untuk membedakan antara daerah yang termasuk dalam garis hitam dan daerah yang termasuk dalam garis berwarna putih.

\section{Sensor Accelerometer}

Sebelum melakukan pengambilan data, hal pertama yang dilakukan adlah menentukan posisi 00 (nol derajat), arah dari sudut -900 dan sudut 900 yang akan digunakan selama melakukan pengukuran pengambilan data. Hubungkan sensor accelometer dengan tegangan, besaran tegangan yang digunakan tergantung dari jenis dan tipe dari sensor accelerometer yang digunakan. Setelah menghubungkan dengan catu daya, lakukan pengukuran tegangan pada keluaran $\mathrm{X}, \mathrm{Y}$ dan $\mathrm{Z}$ pada accelerometer. Kondisi rata dianggap sebagai posisi 00 , kemudian simulasikan sensor pada posisi seolah - olah perangkat dalam kondisi dalam keadaan miring kekiri atau kekanan. Kemudian simulasikan juga gerakan seolah-olah perangkat dalam kondisi menanjak dan menurun.

Tabel 3. Pengukuran Accelerometer 


\begin{tabular}{|c|c|c|c|c|}
\hline \multirow{2}{*}{$\begin{array}{c}\text { Sudut } \\
\text { Kemiringan }\end{array}$} & \multicolumn{3}{|c|}{ Output Analog (V) } & \multirow[t]{2}{*}{ Keterangan } \\
\hline & $\mathrm{x}$ & $\mathrm{Y}$ & Z & \\
\hline$-90^{\circ}$ & 2,425 & 2,558 & 1,366 & \\
\hline$-80^{\circ}$ & 2,418 & 2,554 & 1,489 & \\
\hline$-70^{0}$ & 2,395 & 2,511 & 1,603 & \\
\hline$-60^{\circ}$ & 2,34 & 2,455 & 1,733 & \\
\hline$-50^{\circ}$ & 2,27 & 2,374 & 1,864 & \\
\hline$-40^{\circ}$ & 2,195 & 2,288 & 1,951 & \\
\hline$-30^{0}$ & 2,101 & 2,183 & 2,017 & \\
\hline$-20^{\circ}$ & 1,965 & 2,046 & 2,101 & \\
\hline$-10^{0}$ & 1,81 & 1,897 & 2,138 & \\
\hline $0^{0}$ & 1,68 & 1,75 & 2,15 & \\
\hline $10^{0}$ & 1,566 & 1,631 & 2,141 & \\
\hline $20^{0}$ & 1,358 & 1,5 & 2,097 & \\
\hline $30^{0}$ & 1,261 & 1,309 & 2,026 & \\
\hline $40^{0}$ & 1,169 & 1,263 & 2,020 & \\
\hline $\mathbf{5 0 ^ { 0 }}$ & 1,08 & 1,155 & 1,884 & \\
\hline $60^{0}$ & 0.994 & 1,092 & 1,75 & \\
\hline $70^{0}$ & 0,947 & 0,995 & 1,665 & \\
\hline $80^{0}$ & 0,91 & 0,975 & 1,612 & \\
\hline $90^{\circ}$ & 0,872 & 0,936 & 1,326 & \\
\hline
\end{tabular}

Tabel diatas memberikan gambaran besar tegangan yang dikeluarkan oleh output $\mathrm{X}, \mathrm{Y}$, dan $\mathrm{Z}$ dari sensor accelerometer. Yang mana nilainya akan berubah seiring dengan perubahan sudut yang diukur. Yang menarik untuk diperhatikan adalah nilai yang berubah hanya dua variabel, yaitu jika pengukuran dilakukan terhadap sumbu Y maka variabel yang berubah hanya variabel sumbu $X$ dan variabel sumbu $Z$. Begitu juga sebaliknya apabila pengukuran dilakukan terhadap sumbu $X$, maka variabel yang berubah hanya variabel sumbu $Y$ dan dan variabel sumbu Z. Yang bisa dipahami dalam hal ini adalah jika sumbu $X$ bernilai konstan bisa diasumsikan sebagai pengukuran terhadap kemiringan lintasan, dan jika sumbu $Y$ bernilai konstan bisa di asumsikan sebagai pengukuran terhadap jalan menanjak dan menurun.

\section{Limit Switch}

Pengujian dilakukan menghubungkan limit switch dengan sumber tegangan dan tidak lupa diserikan dengan sebuah resistor untuk menghindari hubung singkat pada saat kontak pada limit switch terhubung. Seperti pada gambar dibawah ini:

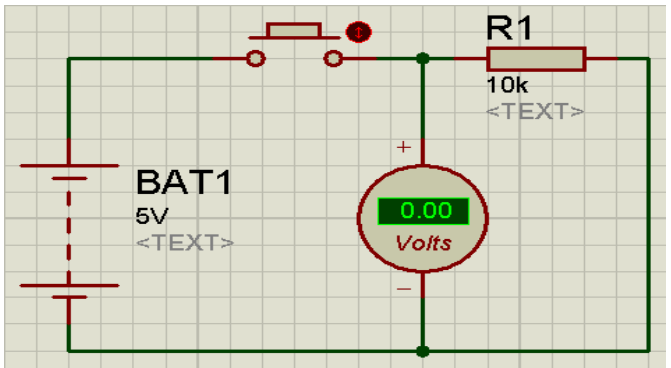

Gambar 12. Cara melakukan pengukuran

Untuk kondisi 0, limit switch tidak ditekan atau OFF. Dan untuk kondisi 1, limit switch dalam posisi di tekan atau ON.

Tabel 4. Pengukuran limit switch

\begin{tabular}{|c|c|c|}
\hline $\begin{array}{c}\text { Kondisi } \\
\text { Switch }\end{array}$ & $\begin{array}{c}\text { Tegangan } \\
(\mathrm{V})\end{array}$ & $\begin{array}{c}\text { Arus } \\
(\mathrm{A})\end{array}$ \\
\hline ON & 5 & 0,020 \\
\hline OFF & 0 & 0 \\
\hline
\end{tabular}

Dari tabel diatas dapat diketahui bahwa limit switch hanya memberikan nilai $\mathrm{ON}$ atau OFF terhadap suatu kondisi. Apabila dihubungan dengan arduino, maka nilai yang didapat adalah nilai digital 0 atau 1 , selanjutnya bisa di olah dengan bahasa pemograman.

\section{Motor Servo}

Perangkat yang diperlukan adalah potensiometer, arduino uno dan motor servo. Hubungkan ketiga perangkat seperti gambar berikut:

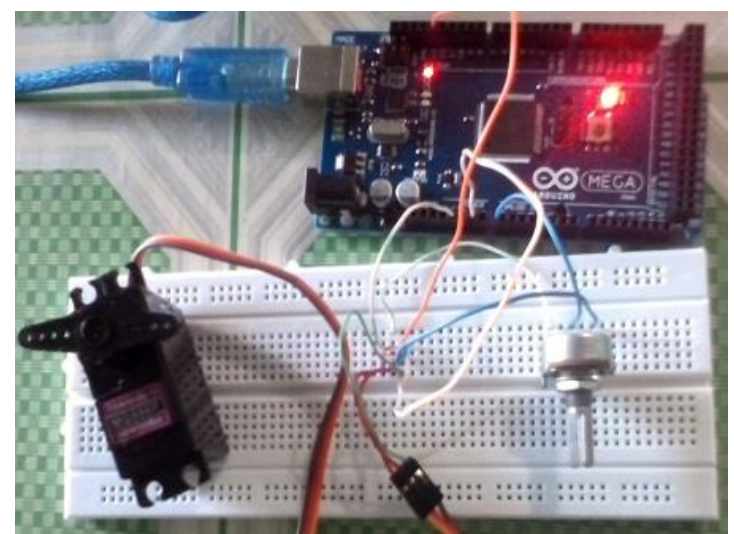

Gambar 13. Rangkaian pengujian motor servo

Salah satu kaki potensiometer dihubungkan pada masukan analog arduino, motor servo diberi catu daya sendiri dan kabel control dihubungkan ke 
keluaran pwm arduino. Hubungkan arduino dengan computer, setelah itu download program pengujian. Untuk menentukan nilai dari masukan analog potensiometer bisa dimonitor pada serial monitor yang telah disiapkan oleh arduino.

Tabel 5. pengukuran motor servo

\begin{tabular}{|c|c|}
\hline Lebar Pulsa(m) & $\begin{array}{l}\text { Arah } \\
\text { Putaran }\end{array}$ \\
\hline 0 & CW \\
\hline 10 & CW \\
\hline 20 & CW \\
\hline 30 & CW \\
\hline 40 & CW \\
\hline 50 & CW \\
\hline 60 & CW \\
\hline 70 & CW \\
\hline 80 & CW \\
\hline 90 & Berhenti \\
\hline 100 & CCW \\
\hline 110 & CCW \\
\hline 120 & CCW \\
\hline 130 & CCW \\
\hline 140 & CCW \\
\hline 150 & CCW \\
\hline 160 & CCW \\
\hline 170 & CCW \\
\hline 180 & CCW \\
\hline & \\
\hline
\end{tabular}

Dari hasil percobaan diatas dapat diketahui bahwa arah putaran dari motor servo ditentukan oleh nilai yang diberikan pada input control motor servo. Apabila nilai yang diberikan mulai 0 sampai 89 maka berputar searah dengan jarum jam. Dan apabila nilai yang diberikan adalah 91 sampai 180, maka putaran berlawanan dengan arah jarum jam. Kecepatan dari motor servo juga bisa diatur dari nilai - nilai yang diberikan pada input controlnya, apabila nilai yang diberikan mendekati nilai 90 . Seperti nilai yang diberikan kecil dari 90 atau lebih besar dari 90 maka servo akan berputar lambat. Dan putaran akan bertambah cepat apabila niali yang diberikan mendekati 0 . Nilai yang control ini bisa diatur menggunakan output pwm pada arduino.

\section{Rencana pengujian arduino}

Pengujian arduino meliputi pengujian terhadap pin-pin arduino seperti pin input analaog, pin output pwm, pin untuk komunikasi dengan modul bluetooth tx dan rx. Pengujian terhadap pin arduino adalah dengan cara menggunakan bahasa pemograman arduino, dan hasil dari eksekusi program bisa dimonitor menggunakan serial monitor.

\section{Pengujian pin analog}

Berikut adalah list program yang digunakan saat memprogram arduino untuk membaca masukan analog :

Int cds1 = 0;

Void setup() \{

Serial.begin(9600);

\}

Void loop() \{

// read analog pin $\mathrm{a} 0$ and display value

// on serial monitor window

Cds1 = analogread $(\mathrm{a} 0)$;

Serial.println(cds1, dec);

Delay (1500);

\}

Adapun tampilan pada sketch arduino adalah sebagai berikut :

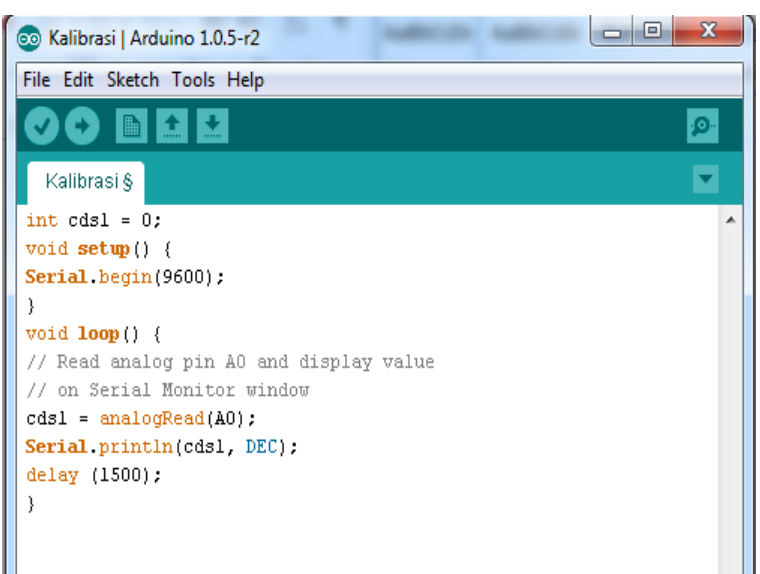

Gambar 14. Listing program pegujian masukan analog

\section{Rencana pengujian keluaran pwm}

Pengujiam dilakukan dengan menggunakan satu masukan analog berupa potensio meter atau vr(variable resistor). List program yang menggunakan:

\#include <servo.h>

// referensi cds cell 
Int masukan_analog $=0$;

Servo servo;

Void setup() \{

Servo.attach(6);

Serial.begin (9600);

\}

Void loop() \{

// baca sensor

// analog pins a0

Masukan_analog $=$ analogread $(\mathrm{a} 0) / 5.7$;

// angka 5,7 digunakan sebagai pembagi agar didapat angka 180

Serial.printIn(masukan_analog,dec);

Delay(1000);

//serial.println digunakan untuk menampilkan masukan analog pada serial monitor

Servo.write(masukan_analog);

\}

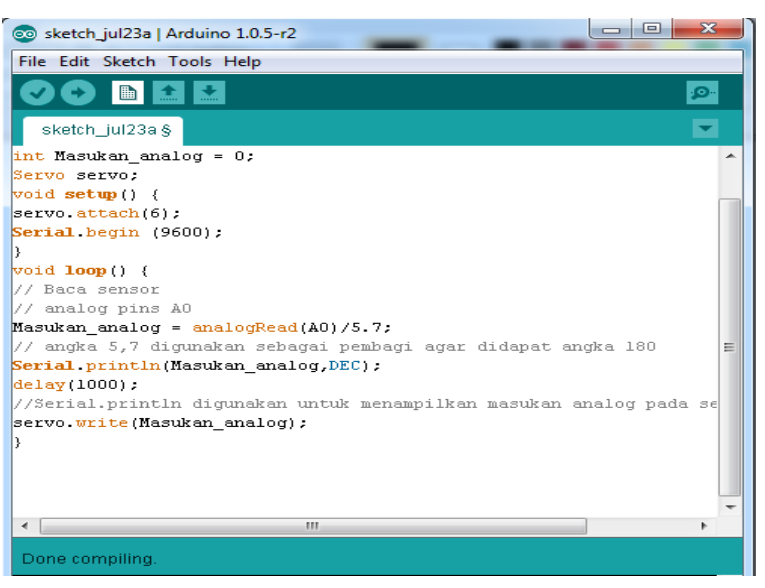

Gambar 15. Listing pengujian motor servo

\section{Penggabungan Program}

Penggabungan dari semua pengujian yang telah dilakukan diharapkan bisa membuat perangkat berjalan seperti yang diharapkan. Pada saat melakukan pengujian secara keseluruhan secara umum robot sudah berjalan sesuai dengan yang direncanakan, yaitu robot berjalan mengikuti desain lintasan yang direncanakan. Robot sudah bisa berjalan melintasan garis yang sudah ditentukan, data kemiringan sudut juga sudah bisa didapatkan dari sensor accelerometer. Dan data juga sudah bisa dikirim melalui media bluetooth, untuk kemudian dibaca pada perangkat lain.

\section{KESIMPULAN}

Setelah melakukan percobaan- percobaan tentang robot line follower untuk pemantuan kondisi jalan, dapat disimpulkan robot bisa berjalan mengikuti lintasannya yang sudah ditentukan dan data dari kondisi jalan juga bisa didapatkan dan dikirim melalui media bluetooth. Simpangan kesalahan dari pengukuran berkisar $20 \%$, hal ini dikarenakan kesulitan pada saat mengkalibrasi alat sehingga besaran kemiringan sudut yang didapat belum menggambarkan kondisi yang sebenarnya. Kelebihan dari alat ini adalah pengaksesan data hasil pengukuran bisa diketahui melalui perangkat lain seperti computer, android dan tablet yang mempunyai aplikasi komunikasi dengan perangkat arduino.

Dibawah ini ada beberapa saran yang mungkin berguna bagi yang membaca penulisan ini, antara lain:

a. LDR yang digunakan sebaiknya mempunyai kepekaan yang tinggi dan respon yag cepat, hal ini berguna untuk menghindari robot keluar dari lintasan.

b. Pada saat robot keluar dari lintasan, sebaiknya tidak menggunakan delay waktu, karena akan sangat berpengaruh pada arah jalan robot selanjutnya.

\section{UCAPAN TERIMAKASIH}

Terima kasih saya ucapkan kepada:

1. Istri tercinta saya

2. Kaprodi Teknik elektro Syaiful B, S.T., M.Eng.Sc., Ph.D.

\section{REFERENCES}

[1] Ginong Pratidhina Nur Muhammad, Prototipe Robot Line Follower Untuk Tunanetra Berbasis Mikrokontroler AVR-ATMEGA328 Dengan Board Modul Arduino UNO R2, 20 Oktober 2013,

[2] Dedi Tambunan, Line Follower Menggunakan Kontrol PID, 20 Oktober 2013.http://repository.gunadarma.ac.id/ 
bitstream/123456789/1354/1/21107865.

pdf

[3] Eko Prasetio, Sistem Gerak Robot Line

Follower Menggunakan Motor DC

Berbesisi Mikrokontroler ATmega8535

Dengan Sensor Photodiode, 20

Oktober 2013,

[4] Feri Djuandi, Pengenalan Arduino, 27 Oktober 2013,

[5] Ribut Puja Siswato, Alat Penghemat Energi Listrik Uuntuk Penerangan Ruangan Dengan Sensor Peka Cahaya Berbasis Mikrokontroler, 19 November 2013,

[6] Wayan Supandi, Dasar Motor Stepper, 19 November 2013,

[7] Samsudin, Arief Wahyu Hidayat, Perancangan dan Implementasi Alat Pembaca Skala Neraca Secara Digital Dengan Sensor Accelerometer MMA7361 Yang Ditampilkan Pada Display 2x16, 22 Januari 2014

[8] Kadir,Abdul. Panduan Praktis Mempelajari Aplikasi Mikrokontroler dan Pemogramannya Menggunakan Arduino. Penerbit Andi, Yogyakarta, 2012. 